\title{
Applications of polymerase chain reaction for the detection of equine Leishmania sp. infection
}

\section{Aplicação da reação em cadeia da polimerase na deteç̧ão da infecção por Leishmania sp. em equinos}

\author{
Taiane Acunha Escobar ${ }^{1 *}$; Gabriela Döwich ${ }^{2}$; Leticia Carvalho Cantele ${ }^{3}$; \\ Geórgia Camargo Góss²; Marcelo Lameiro Porciúncula; Carla Teixeira Leite ${ }^{5}$; \\ Luísa Zuravski ${ }^{1}$; Claudia Acosta Duarte ${ }^{6}$; Irina Lübeck ${ }^{6}$
}

\begin{abstract}
Leishmaniasis is a neglected zoonotic disease caused by a variety of pathogenic Leishmania species. In the New World, especially in Brazil, visceral leishmaniasis (VL) is caused by Leishmania infantum. The pathogen can infect several animal species including dogs, foxes, rodents, primates, felines, equines and humans. Dogs act as the primary domestic reservoirs. This study aimed to use polymerase chain reaction (PCR) for detecting Leishmania infection in horses living in a canine visceral leishmaniasis (CVL) endemic region. DNA samples from horse peripheral blood were used to perform PCR. Templates were amplified using primers for the kinetoplast DNA (kDNA) minicircles, which were able to detect different species of Leishmania. In addition, primers for internal transcribed spacer (ITS) of ribosomal DNA were used for detection of Trypanosomatidae sp. Amongst the 75 (39\%) positive PCR samples from total 192 samples, 21 samples were positive for kDNA and 63 samples were positive for either ITS, ITS1, or ITS2 gene markers. The kDNA PCR and sequencing allowed the detection of $L$. infantum in horse blood samples. To our knowledge, this is the first report of equine infection with $L$. infantum in Southern Brazil. These results proved that $L$. infantum could also infect horses in addition to humans and dogs, as well as in European countries. This conclusion emphasizes the urgent need to follow up investigation of the infection in these animals.
\end{abstract}

Key words: Leishmania infantum. Diagnostic methods. Infection. Horses.

\section{Resumo}

A leishmaniose é uma doença zoonótica negligenciada, causada por uma diversidade de espécies patogênicas de Leishmania. No Novo Mundo, especialmente no Brasil, a leishmaniose visceral é causada pelo protozoário Leishmania infantum. A infecção acomete várias espécies animais (cães,

1 Doutoras em Bioquímica, Programa de Pós-Graduação em Bioquímica, Universidade Federal do Pampa, UNIPAMPA, Uruguaiana, RS, Brasil. E-mail: taianeescobar@hotmail.com; luizazuravski@gmail.com

2 Discentes de Mestrado, Programa de Pós-Graduação em Ciência Animal, UNIPAMPA, Uruguaiana, RS, Brasil. E-mail: gabrieladowich@hotmail.com; georgia_goss@hotmail.com

3 Médica Veterinária, Graduação em Medicina Veterinária, UNIPAMPA, Uruguaiana, RS, Brasil. E-mail: leticiaccantele@hotmail. com

4 Prof., Curso de Medicina Veterinária, Universidade da Região da Campanha, URCAMP, Alegrete, RS, Brasil. E-mail: marceloporciuncula@urcamp.edu.br.

5 Doutora em Medicina Veterinária, Programa de Pós-Graduação em Medicina Veterinária, Universidade Estadual Paulista, UNESP, Jaboticabal, SP, Brasil. E-mail: carlateixeiraleite@hotmail.com

6 Profs., Curso de Graduação em Medicina Veterinária, UNIPAMPA, Uruguaiana, RS, Brasil. E-mail: claudiaduarte@unipampa. edu.br; irinalubeck@unipampa.edu.br

* Author for correspondence 
raposas, roedores, primatas, felinos, equinos) e humanos e o cão é o principal reservatório doméstico. Este estudo teve como objetivo utilizar a reação em cadeia da polimerase (PCR) para detectar a infecção por Leishmania sp. em cavalos que vivem em uma região endêmica para leishmaniose visceral canina (LVC). Amostras de DNA do sangue periférico de equinos foram utilizadas para extração de DNA e PCR. As amplificações foram realizadas utilizando-se marcadores para a região do DNA do cinetoplasto (kDNA), que são capazes de detectar diferentes espécies de Leishmania sp. e a região dos espaçadores internos transcritos (ITS) do DNA ribossomal para detecção da família Trypanosomatidae. Dentre os 192 animais testados, 75 (39\%) amostras foram positivas no PCR, 21 amostras foram positivas para PCR kDNA e 63 para os genes ITS, ITS1 e ITS2. O sequenciamento dos amplicons permitiu detectar $L$. infantum em amostras de sangue periférico de equinos. Este foi o primeiro relato de infecção por $L$. infantum no sul do Brasil na espécie equina. Os resultados demonstram que, assim como nos países europeus, a infecção foi detectada em equinos após ter sido identificada em seres humanos e cães, o que indica a urgência em acompanhar a investigação da infecção nessa espécie animal.

Palavras-chave: Leishmania infantum. Métodos diagnósticos. Infecção. Cavalos.

\section{Introduction}

Leishmaniasis is caused by different Leishmania spp. and is transmitted by phlebotomine sand flies during blood meal. The main reservoirs of Leishmania infantum in many areas of the world in the peridomestic or sylvatic environments are domestic dogs and wild foxes, respectively (Lainson \& Rangel, 2005). Apart from humans, several mammalian species, including rodents, primates, felines and equines are infected by the pathogen and participate in the epidemiological chain to ensure proliferation of the etiological agent (Benassi et al., 2017; Echchakery et al., 2017; Lombardi et al., 2014; Müller, Hentrich, Frey, \& Welle 2015). With numerous leishmaniasis outbreaks described in mammals, they are incriminated as possible reservoirs or accidental hosts (Figueiredo \& Madeira, 2014).

Leishmania infection was detected in equines from endemic regions in Europe and SouthEast Brazil (Feitosa et al., 2012; Gama et al., 2014; Koehler et al., 2002; Soares et al., 2013; Solano\&Gallego et al., 2003). The equines are a potential food source for phlebotomines in the peridomiciliary environment and could be involved in the cutaneous leishmaniasis cycle. Horse-blood was sufficient to support sand fly oviposition, as seen by experimentally feeding $L$. longipalpis with blood meals from different animal sources (Macedo-Silva et al., 2014; Truppel et al., 2014).
In the New World, visceral leishmaniasis (VL) is caused by Leishmania infantum (syn. L. chagasi) (Belo et al., 2013). Leishmaniasis has spread rapidly in Brazilian territory. Southern region was free of VL and canine visceral leishmaniasis (CVL) until the last decade when the first cases were identified. Rio Grande do Sul's western border witnessed the identification of seropositive dogs in several neighborhoods, including riverside and continental locations (Escobar et al., 2018) and was therefore, classified as a VL transmission area since 2008 (Deboni, Barbosa, \& Ramos, 2011).

In Brazil, serological techniques are the gold standard for diagnosis of VL and CVL. The protocols and standardized kits produced and distributed by Brazilian Ministry of Health have limited reach, and are effective only in human and canine species (Ministério da Saúde, 2014). These methods have lower sensitivity of detection of Leishmania infection than that of molecular tests (Lopes et al., 2017). In addition to serological methods, conventional diagnosis of VL relies on histological examination of skin biopsy or lymph node puncture samples. Although histology can be facilitated by immunohistochemistry, identifying the intracellular amastigote is difficult, particularly in sections containing few parasites (Ministério da Saúde, 2014; Lombardo, Pennisi, Lupo, Chicharro, \& Solano-Gallego 2014). 
Recently, molecular techniques are being applied to detect Leishmania infection and classify parasites to genus, complex or species levels (Pita-Pereira et al., 2012). Leishmania genetic markers can be identified by PCR to achieve detection at the genus level, or depending on the targets and the respective primers, the assay can be designed to be genusspecific or species-specific (Akhoundi et al., 2017).

Trypanosomatids, including Leishmania spp., have unique genomic organization traits compared to other eukaryotes, such as genes without introns, polycistrons, and small chromosomes with high-density genes. A single Trypanosomatid mitochondrion carries large kinetoplast DNA (kDNA) that cannot be found in any other species (Akhoundi et al., 2017; Lukeš et al., 2002). The parasite can be detected by using gene markers encoding non-chromosomal DNA, kDNA regions for the genus Leishmania (A-B; LINR4-LIN17LIN19) or specific primers for L. infantum (RV1RV2; MC1-MC2) (Cortes, Rolão, Ramada, \& Campino, 2004; Le Fichoux et al., 1999; Pandey et al., 2008).

The ribosomal DNA (rDNA), mostly located on chromosome 27, has the most variable ITS (internal transcribed spacer) regions, which are ideal for species-typing (Kuhls, Mauricio, Pratlong, Presber, \& Schönian, 2005; Schönian et al., 2001). They can also be used as molecular targets using LITSR/ L5.8S, LITSV/LITSR, and LITSV/L5.8SR primers (El Tai et al., 2000; El Tai et al., 2001). However, using the primer-BLAST tool, it has been observed that these primers can amplify regions of other trypanosomatids, including Trypanosoma cruzi with products ranging from $300-760 \mathrm{bp}$.

Owing to the diversity of the Leishmania spp. that is potentially present in hosts, we performed PCR to focus on the amplification of nonchromosomal kDNA minicircles and chromosomal DNA of ITS rDNA to detect Leishmania infection in the peripheral blood of horses living in a CVLendemic region.

\section{Materials and Methods}

\section{Ethical approval}

This study protocol was approved by the Ethics Committee on Animal Experimentation of the Federal University of Pampa (CEUA UNIPAMPA number 029-2013). All animals were treated according to Brazilian National Guidelines on Animal Experimentation Law 11794-DOU ${ }^{7}$ (8 October 2008). All efforts were made to minimize animal suffering. Before animal participation, owners' authorizations were obtained through the informed consent form for data and biological material collection.

\section{Animals}

Blood samples were collected from urban perimeter of Uruguaiana, Rio Grande do Sul

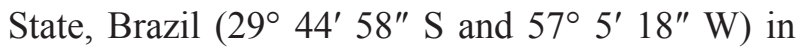
partnership with 'Projeto Carroceiro' developed by the Equipampa Group of the UNIPAMPA Veterinary Medicine. All animals were subjected to clinical evaluation to verify physical and physiological conditions prior to blood collection. The presence of possible skin changes was observed carefully. The neighborhoods involved in this study were classified according to the local postal code. The study included animals of unknown origin, which were seized during inspection by the Federal Highway Police. According to the enrolment criteria, animals were selected only if (1) they were draught animals (2) and they originated from the municipality's urban area. Samples were grouped by the known origin (KO) of the animals or seized animals (SA). Horses were excluded if they were not domiciled in the urban perimeter or not used as a draught animal.

\footnotetext{
${ }^{7}$ See: http://www.planalto.gov.br/ccivil_03/_ato2007-2010/2008/lei/111794.htm
} 
We used 192 peripheral blood samples $(10 \mathrm{~mL})$ collected from horses (Equus ferus caballus) by venipuncture of the external jugular vein. Samples were maintained in tubes with EDTA to extract the genetic material from the whole blood and were stored at $-20^{\circ} \mathrm{C}$ until further processing.

\section{Molecular diagnosis}

DNA was purified from blood samples by salting out method (Sambrook \& Russel, 2001). Briefly, $500 \mu \mathrm{L}$ of whole blood was added to $1.5 \mathrm{~mL}$ polypropylene microcentrifuge tubes containing $500 \mu \mathrm{L}$ lysis buffer, $1 \%$ Triton X-100, centrifuged at $17949.49 \mathrm{~g}$ for $1 \mathrm{~min}$, and the supernatant was discarded. This step was repeated until a clear pellet was obtained. RCLB buffer was then added to the pellet. The dried pellet was resuspended in proteinase $\mathrm{K}$ solution $(25 \mathrm{mg} / \mathrm{mL})$ containing $1 \mathrm{X}$
TEM and sodium dodecyl sulfate (SDS), at $56^{\circ} \mathrm{C}$ for $1 \mathrm{~h}$ to proceed with DNA extraction. Next, 5 $\mathrm{M} \mathrm{NaCl}$ was added and the solution was mixed for $15 \mathrm{~s}$ followed by centrifugation at $17949.49 \mathrm{~g}$ for $5 \mathrm{~min}$. The supernatant was transferred into a new $1.5 \mathrm{~mL}$ tube containing ice-cold isopropyl alcohol and stored at $-20^{\circ} \mathrm{C}$ for $30 \mathrm{~min}$. Then, $1 \mathrm{~mL}$ of $70 \%$ ethanol was added and the DNA was pelleted by centrifugation at $10621 \mathrm{~g}$ for $2 \mathrm{~min}$ at $4^{\circ} \mathrm{C}$. The DNA pellet was dried for $15 \mathrm{~min}$ at room temperature $\left(30^{\circ} \mathrm{C}\right)$. The dried DNA pellet was resuspended in $100 \mu \mathrm{L} \mathrm{TE}$ buffer and stored at $-20^{\circ} \mathrm{C}$. The isolated DNA was quantified using a spectrophotometer.

The DNA was subjected to PCR using primers for four different gene regions to detect Leishmania infection. Primers were used to amplify fragments of kDNA sequence LT1 as well as ITS, ITS1 and ITS2 subunit ribosome genes of the Leishmania spp. (Table 1)

\section{Table 1}

The details of PCR for four primer sequences and the main conditions for detection of Leishmania infection in equine peripheral blood

\begin{tabular}{|c|c|c|c|c|c|}
\hline $\begin{array}{l}\text { Gene } \\
\text { region }\end{array}$ & Primer & $\begin{array}{l}\text { Product } \\
\text { size }\end{array}$ & $\begin{array}{l}\text { Primer sequence } \\
\left(5^{\prime}-3^{\prime}\right)\end{array}$ & $\begin{array}{l}\text { Analysis by } \\
\text { BLAST }\end{array}$ & $\begin{array}{l}\text { Amplification } \\
\text { Conditions }\end{array}$ \\
\hline $\begin{array}{l}\text { ITS } \\
\text { rDNA }\end{array}$ & $\begin{array}{l}\text { LITSV } \\
\text { LITSR }\end{array}$ & 1020 & $\begin{array}{l}\text { ACACTCAGGTCTGTAAAC } \\
\text { CTGGATCATTT-TCCGATG }\end{array}$ & $\begin{array}{l}\text { Trypanosoma- } \\
\text { tidae sp. }\end{array}$ & $\begin{array}{l}95^{\circ} \mathrm{C} / 2 \mathrm{~min}, 95^{\circ} \mathrm{C} / 20 \mathrm{~s}, \\
53^{\circ} \mathrm{C} / 30 \mathrm{~s}, 72^{\circ} \mathrm{C} / 60 \mathrm{~s} \\
(34 \text { cycles }), 72^{\circ} \mathrm{C} / 6 \mathrm{~min} \\
\text { (El Tai et al., } 2000)\end{array}$ \\
\hline $\begin{array}{l}\text { ITS1 } \\
\text { rDNA }\end{array}$ & $\begin{array}{l}\text { LITSR } \\
\text { L5.8S }\end{array}$ & 320 & $\begin{array}{l}\text { CTGGATCATTT-TCCGATG } \\
\text { TGATACCACTTATCGCACTT }\end{array}$ & $\begin{array}{l}\text { Trypanosoma- } \\
\text { tidae sp. }\end{array}$ & $\begin{array}{l}95^{\circ} \mathrm{C} / 2 \mathrm{~min}, 95^{\circ} \mathrm{C} / 20 \mathrm{~s}, \\
53^{\circ} \mathrm{C} / 30 \mathrm{~s}, 72^{\circ} \mathrm{C} / 60 \mathrm{~s} \\
(34 \text { cycles }), 72^{\circ} \mathrm{C} / 6 \mathrm{~min} \\
\text { (El Tai et al., } 2001 \text { ) }\end{array}$ \\
\hline $\begin{array}{l}\text { ITS2 } \\
\text { rDNA }\end{array}$ & $\begin{array}{l}\text { LITSV } \\
\text { L5.8SR }\end{array}$ & 700 & $\begin{array}{l}\text { ACACTCAGGTCTGTAAAC } \\
\text { AAGTGCG-ATAAGTGGTA }\end{array}$ & $\begin{array}{l}\text { Leishmania } \\
\text { spp. } \\
\text { Trypanosoma } \\
\text { spp. }\end{array}$ & $\begin{array}{l}95^{\circ} \mathrm{C} / 2 \mathrm{~min}, 95^{\circ} \mathrm{C} / 20 \mathrm{~s}, \\
53^{\circ} \mathrm{C} / 30 \mathrm{~s}, 72^{\circ} \mathrm{C} / 60 \mathrm{~s} \\
(34 \text { cycles }), 72^{\circ} \mathrm{C} / 6 \mathrm{~min} \\
(\text { El Tai et al., } 2001)\end{array}$ \\
\hline $\begin{array}{l}\text { LT1 } \\
\text { kDNA }\end{array}$ & $\begin{array}{l}\text { RV1 } \\
\text { RV2 }\end{array}$ & 145 & $\begin{array}{l}\text { СTTTCTGGTCCCGCGGGTAGG } \\
\text { CCACCTGGCCTATTTTACACCA }\end{array}$ & $\begin{array}{l}\text { Leishmania } \\
\text { infantum, } \\
\text { Leishmania } \\
\text { donovani, } \\
\text { Leishmania } \\
\text { major, } \\
\text { Leishmania } \\
\text { amazonensis }\end{array}$ & $\begin{array}{l}94^{\circ} \mathrm{C} / 4 \mathrm{~min}, 94^{\circ} \mathrm{C} / 30 \mathrm{~s}, \\
60^{\circ} \mathrm{C} / 30 \mathrm{~s}, 72^{\circ} \mathrm{C} / 30 \mathrm{~s} \\
(30 \text { cycles }), 72^{\circ} \mathrm{C} / 10 \mathrm{~min} \\
\text { (Almeida et al., } 2013 \text {; } \\
\text { Le Fichoux et al., 1999; } \\
\text { R. C. Silva, Richini-Pe- } \\
\text { reira, Kikuti, Marson \& } \\
\text { Langoni } 2017)\end{array}$ \\
\hline
\end{tabular}


The reactions mixture was composed of $2.5 \mathrm{U}$ Taq DNA polymerase, $1 \mathrm{X}$ PCR buffer, $1.5 \mathrm{mM} \mathrm{MgCl}_{2}$ (Invitrogen), $10 \mathrm{mM}$ of each dNTP (Promega), 10 pmol of each primer (Integrated DNA Technologies), $8 \mu \mathrm{L}$ ultrapure water, and $8 \mu \mathrm{L}$ sample with a final volume of $25 \mu \mathrm{L}$. The amplification reactions were performed in a thermocycler (Amplitherm Thermal Cyclers TX96 plus) with denaturation, annealing, and extension in accordance with an established protocol (Table 1). The DNA samples of $L$. infantum (MOHM/BR/1974/PP75 and MOHM/BR/2002/ LPC-RPV) and L. donovani (MOHM/ET/1976/ HU3) provided by the CLIOC - Oswaldo Cruz Institute (FIOCRUZ) ${ }^{8}$ were used as the positive controls. Whereas, milli-Q water was used as a negative control for all molecular techniques.

The amplicons were examined by electrophoresis through $1.5 \%$ agarose gel stained with ethidium bromide and visualized on an AlphaImager gel documentation system with ultraviolet light. The amplicons were purified by employing a Purelink ${ }^{\text {TM }}$ Quick Gel Extraction and PCR Purification kit (Invitrogen). The sequencing reactions were conducted for both strands in an ABI-Prism 3500 Genetic Analyzer (Applied Biosystems by Life Technologies). The obtained sense and antisense sequences were analyzed using Chromas 2.3 software (Technelysium Pyt Ltd.) and compared using the GenBank database - BLAST to confirm the presence and identity of each parasite. The primers and amplicons were subjected to Basic Local Alignment Search Tool (BLAST) ${ }^{9}$ analysis to identify the maximum identity and query coverage with other microorganisms.

\section{Results}

We selected 192 horses from 10 neighborhood areas of Uruguaiana, RS, Brazil. All animals were evaluated for clinical conditions. Both infected and non-infected animals (as detected by PCR assays) failed to show clinical signs suggestive of skin changes, such as lesions, nodules, and ulcers on the body. Thus, there was no relationship between clinical signs in infected horses and Leishmania infection.

The PCR assays to detect Leishmania infection were performed with four sets of primers in order to increase the efficiency of detection and to compare the different markers in two molecular regions. With this assay, we managed to point out DNA fragments in 75 horse samples. When analyzing the results individually, we verified that the kDNA region, amplified with RV1/RV2 primer pair showed positive results in 21 samples. For the rDNA region ITS (internal transcribed spacer), three primer pairs were used: ITS (LITSV/LITSR), ITS1 (LITSR/ L5.8S) and ITS2 (LITSV/L5.8SR), which amplified DNA fragments in 63 samples of at least one of the ITS regions used (Table 2).

The comparison of four sets of PCR assays revealed differences between the molecular markers used (Table 2), however, there was agreement between ITS/ITS2 of 15 positive samples and between ITS1/ITS2 of two samples. Nine of kDNA positive samples were positive for ITS2 and three were positive for ITS too. Direct sequencing and amplicons analysis of kDNA gene markers were performed to confirm the identity of protozoan species in these three samples. On comparison using the BLAST database, the sequence showed 93\% identity to the $L$. donovani kinetoplast minicircles DNA, isolate MOHM/SD/85/FORSTER/clone7 (GenBank Accession No. AJ010080) and 100\% identity to the L. infantum minicircles DNA, partial sequence (GenBank Accession No. AF027577.1).

\footnotetext{
${ }^{8}$ See: CLIOC -Leishmania Collection direction insert: http://clioc.fiocruz.br/index?services (accessed 14 March 2014).

${ }^{9}$ See: https://blast.ncbi.nlm.nih.gov (accessed 10 November 2017)
} 
Table 2

Detection of Leishmania spp. in equine peripheral blood samples

\begin{tabular}{|c|c|c|c|c|c|}
\hline $\mathbf{N}^{0}$ & $\begin{array}{c}\text { Animal } \\
\text { Registration }\end{array}$ & $\begin{array}{c}\text { RV1/ } \\
\text { RV2 = 21 }\end{array}$ & $\begin{array}{c}\text { LISTSV } / \\
\text { LITSR }=33\end{array}$ & $\begin{array}{c}\text { LITSR/ } \\
\mathrm{L5.8S}=3\end{array}$ & $\begin{array}{c}\text { LISTSV } \\
\text { L5.8SR }=44 \\
\end{array}$ \\
\hline 1 & $1 \mathrm{~A}$ & $\mathrm{X}$ & - & - & $\mathrm{X}$ \\
\hline 2 & $2 \mathrm{~A}$ & - & - & - & $\mathrm{X}$ \\
\hline 3 & $3 \mathrm{~A}$ & $X$ & - & - & $X$ \\
\hline 4 & $4 \mathrm{~A}$ & - & $\mathrm{X}$ & - & - \\
\hline 5 & $5 \mathrm{~A}$ & - & $\mathrm{X}$ & - & $\mathrm{X}$ \\
\hline 6 & $6 \mathrm{~A}$ & $\mathrm{X}$ & $\mathrm{X}$ & - & $\mathrm{X}$ \\
\hline 7 & $8 \mathrm{~A}$ & - & $X$ & - & - \\
\hline 8 & $9 \mathrm{~A}$ & - & - & - & $\mathrm{X}$ \\
\hline 9 & $10 \mathrm{~A}$ & - & $X$ & - & - \\
\hline 10 & $11 \mathrm{~A}$ & $\mathrm{X}$ & - & - & $\mathrm{X}$ \\
\hline 11 & $12 \mathrm{~A}$ & - & $X$ & - & - \\
\hline 12 & $1 \mathrm{~B}$ & $\mathrm{X}$ & $\mathrm{X}$ & - & $\mathrm{X}$ \\
\hline 13 & $2 \mathrm{~B}$ & - & - & - & $\mathrm{X}$ \\
\hline 14 & $3 \mathrm{~B}$ & - & $X$ & - & $\mathrm{X}$ \\
\hline 15 & $9 \mathrm{~B}$ & - & $X$ & - & $\mathrm{X}$ \\
\hline 16 & $14 \mathrm{~B}$ & - & $\mathrm{X}$ & - & $\mathrm{X}$ \\
\hline 17 & $1 \mathrm{C}$ & $\mathrm{X}$ & - & - & - \\
\hline 18 & $4 \mathrm{C}$ & - & $X$ & - & - \\
\hline 19 & $6 \mathrm{C}$ & - & $X$ & - & - \\
\hline 20 & $8 \mathrm{C}$ & - & $X$ & - & - \\
\hline 21 & $9 \mathrm{C}$ & - & $\mathrm{X}$ & - & - \\
\hline 22 & $4 \mathrm{P}$ & $X$ & - & - & - \\
\hline 23 & $6 \mathrm{P}$ & $X$ & - & - & - \\
\hline 24 & $10 \mathrm{P}$ & $\mathrm{X}$ & - & - & - \\
\hline 25 & $13 \mathrm{P}$ & - & - & - & $\mathrm{X}$ \\
\hline 26 & $15 \mathrm{P}$ & - & - & - & $X$ \\
\hline 27 & $17 \mathrm{P}$ & - & - & - & $X$ \\
\hline 28 & $23 \mathrm{P}$ & - & - & - & $X$ \\
\hline 29 & 1469 & - & - & - & $X$ \\
\hline 30 & $1 \mathrm{~T}$ & $X$ & - & - & - \\
\hline 31 & $2 \mathrm{~T}$ & $X$ & - & - & $X$ \\
\hline 32 & $3 \mathrm{~T}$ & $X$ & - & - & - \\
\hline 33 & $5 \mathrm{~T}$ & $X$ & - & - & - \\
\hline 34 & $7 \mathrm{~T}$ & $X$ & - & - & - \\
\hline 35 & $1 \mathrm{D}$ & - & $X$ & - & $X$ \\
\hline 36 & $3 \mathrm{D}$ & - & $X$ & - & $X$ \\
\hline 37 & $7 \mathrm{D}$ & $X$ & - & - & - \\
\hline 38 & $8 \mathrm{D}$ & $X$ & $X$ & - & $X$ \\
\hline
\end{tabular}


continuation

\begin{tabular}{|c|c|c|c|c|c|}
\hline 39 & $9 \mathrm{D}$ & - & $X$ & - & $X$ \\
\hline 40 & $10 \mathrm{D}$ & - & $X$ & - & - \\
\hline 41 & $11 \mathrm{D}$ & - & - & - & $X$ \\
\hline 42 & $12 \mathrm{D}$ & - & - & - & $X$ \\
\hline 43 & $13 \mathrm{D}$ & $X$ & - & - & $X$ \\
\hline 44 & $17 \mathrm{D}$ & - & $X$ & - & - \\
\hline 45 & $19 \mathrm{D}$ & - & $X$ & - & $X$ \\
\hline 46 & $20 \mathrm{D}$ & - & $X$ & - & - \\
\hline 47 & $22 \mathrm{D}$ & - & $X$ & - & - \\
\hline 48 & $1 \mathrm{E}$ & $X$ & - & - & X \\
\hline 49 & $2 \mathrm{E}$ & $X$ & - & - & - \\
\hline 50 & $3 \mathrm{E}$ & - & - & - & X \\
\hline 51 & $6 \mathrm{E}$ & $X$ & - & - & - \\
\hline 52 & $9 \mathrm{E}$ & $X$ & - & - & - \\
\hline 53 & $10 \mathrm{E}$ & - & - & - & $\mathrm{X}$ \\
\hline 54 & $11 \mathrm{E}$ & - & $X$ & - & - \\
\hline 55 & $13 \mathrm{E}$ & - & - & - & $\mathrm{X}$ \\
\hline 56 & $4 \mathrm{~F}$ & - & - & - & $X$ \\
\hline 57 & $6 \mathrm{~F}$ & - & $X$ & - & - \\
\hline 58 & $1 \mathrm{G}$ & - & $X$ & - & - \\
\hline 59 & $2 \mathrm{G}$ & - & $X$ & - & - \\
\hline 60 & $3 \mathrm{G}$ & - & $X$ & - & - \\
\hline 61 & $5 \mathrm{G}$ & - & $X$ & - & - \\
\hline 62 & $6 \mathrm{G}$ & - & $X$ & - & $\mathrm{X}$ \\
\hline 63 & $7 \mathrm{G}$ & - & $X$ & - & $\mathrm{X}$ \\
\hline 64 & $8 \mathrm{G}$ & - & - & - & $\mathrm{X}$ \\
\hline 65 & $9 \mathrm{G}$ & - & - & - & X \\
\hline 66 & $10 \mathrm{G}$ & - & $X$ & - & $\mathrm{X}$ \\
\hline 67 & $11 \mathrm{G}$ & - & - & - & $\mathrm{X}$ \\
\hline 68 & $12 \mathrm{G}$ & - & $X$ & - & $X$ \\
\hline 69 & 810 & - & - & - & $X$ \\
\hline 70 & 847 & - & - & - & $X$ \\
\hline 71 & 922 & - & - & - & $\mathrm{X}$ \\
\hline 72 & 938 & - & - & $X$ & X \\
\hline 73 & 945 & - & - & $X$ & - \\
\hline 74 & 946 & - & - & $X$ & $\mathrm{X}$ \\
\hline 75 & 960 & - & - & - & $X$ \\
\hline
\end{tabular}

The equine samples from 10 neighborhood areas were analyzed and Leishmania infection was detected in seven neighborhoods of Uruguaiana as well as in the SA (Figure 1). Majority of the positive results belonged to three regions, with the highest number of samples corresponding to the municipality. In addition, eight (4.16\%) animals were positive among the SA (Table 3). 


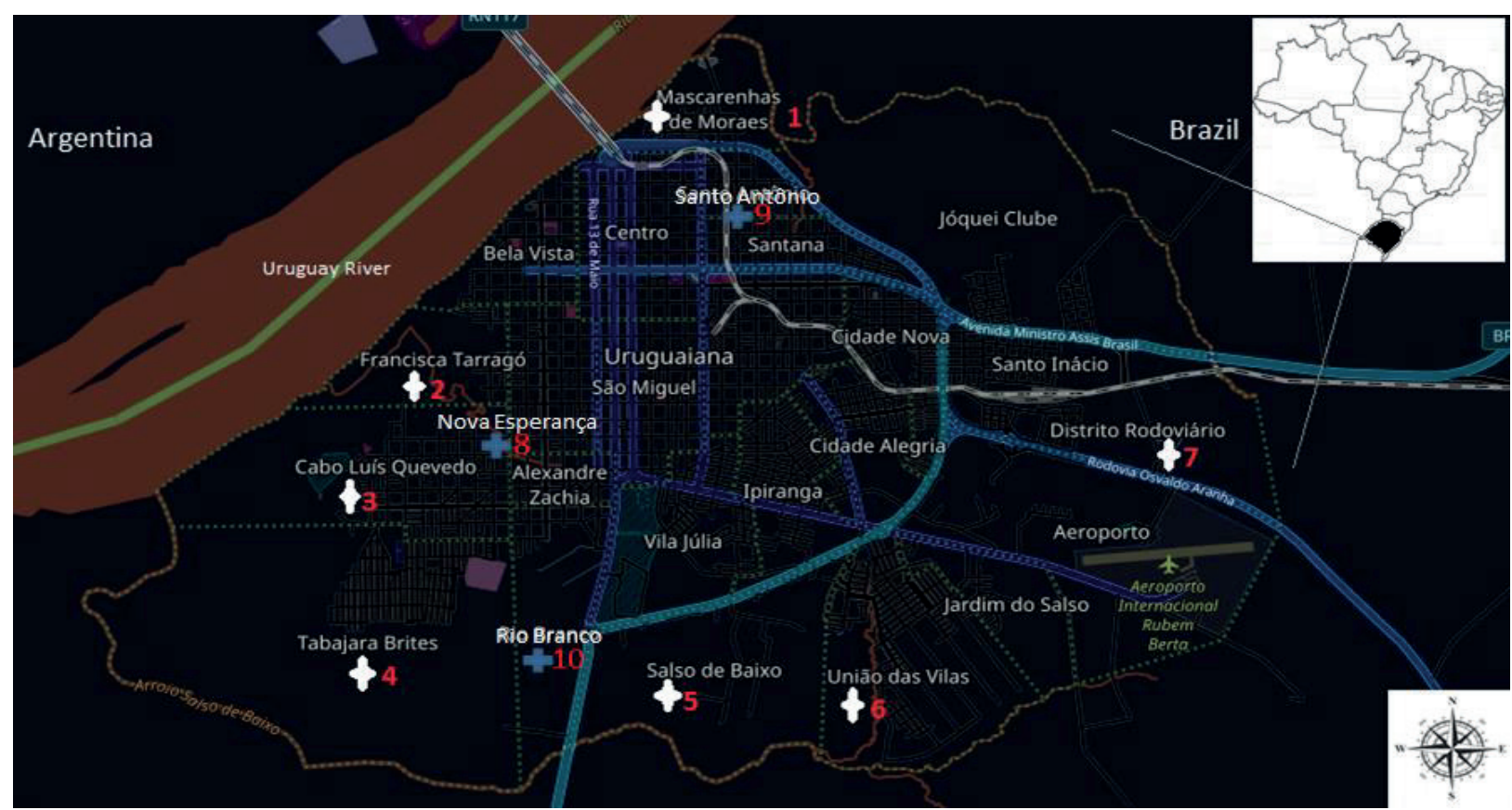

Figure. 1.

Local map showing the study area from Uruguaiana municipality, Southern Brazil. Numbers 1-7 indicate the sampling neighborhoods and direction regions in which horses infected with Leishmania infantum were diagnosed. Numbers 8-10 indicate neighborhoods with non-infected horses.

Table 3

Results of Leishmania infantum infection of equine blood samples collected from different neighborhoods in Uruguaiana, Southern Brazil as confirmed by PCR diagnostic assay

\begin{tabular}{lllll}
\hline $\begin{array}{l}\text { Direction } \\
\text { Region }\end{array}$ & Neighborhoods & $\begin{array}{l}\text { Neighborhoods with } \\
\text { CVL notification }{ }^{\text {a }}\end{array}$ & Sample Size & \% Infected equines \\
\hline North & Mascarenhas de Moraes & Yes & $2 / 3$ & 1.04 \\
North & Santo Antônio & Yes & $0 / 1$ & 0 \\
East & Distrito Rodoviário & Yes & $1 / 3$ & 0.52 \\
East & Salso de Baixo & Yes & $16 / 24$ & 8.33 \\
East & União das Vilas & Yes & $21 / 51$ & 10.94 \\
West & Cabo Luiz Quevedo & Yes & $25 / 54$ & 13.02 \\
West & Francisca Tarrago & Yes & $1 / 3$ & 0.52 \\
West & Tabajara Brites & Yes & $1 / 4$ & 0.52 \\
West & Nova Esperança & Yes & $0 / 21$ & 0 \\
West & Rio Branco & Yes & $0 / 4$ & 0 \\
Unknown & Seized Animals & & $8 / 24$ & 4.17 \\
Total & & - & $75 / 192$ & \\
\hline
\end{tabular}

${ }^{a}$ Cases of canine visceral leishmaniasis notified by the Sanitary Surveillance of the municipality of Uruguaiana, RS in 2012.

${ }^{\mathrm{b}}$ Federal Highway Police. 


\section{Discussion}

Several target sequences and PCR protocols have been described for detection of Leishmania in mammalian hosts, which allow detection of the parasite in diverse types of samples (Dantas-Torres, 2009; Lombardi et al., 2014; Souza et al., 2010). In this study, we aimed to enhance the efficiency of Leishmania detection in equine blood samples using four sets of primers specific for different gene encoding regions. We chose peripheral blood for analysis in order to avoid invasive sampling methods. The advantage of this procedure was the simplicity of collection. This was especially useful when numerous draught animals were analyzed in the field, which would be subjected to physical exertion after sample collection. Although biological samples such as skin, lymph node aspirates, bone marrow aspirates, and buffy coat can exhibit higher PCR sensitivity in dogs and humans (Almeida et al., 2013), they are typically obtained by invasive methodologies and carry possible complications.

Here, we have noticed protozoan DNA in 75 blood samples using at least one primer pair in PCR assay. The results showed that ITS gene markers could detect Leishmania parasites in infected blood samples without the need of prior cultivation. However, these primers showed homology not only for the sequences of Leishmania genus but also for multiple regions of other trypanosomatids, including T. cruzi (M.A. L. de. Silva, Medeiros, Brandão-Filho, Melo, \& Medeiros, 2010). ITS1 and ITS2 regions have a sufficiently high sequence conservation to be Leishmania-specific PCR targets. Therefore, they are valuable regions for species-typing. However, molecular tools such as sequencing and restriction fragment length polymorphism (RFLP) are required for differentiation between species and further characterization of the parasite (Brito \& Pita-Pereira, 2014; El Tai et al., 2000; Schönian et al., 2003). These gene markers have already been used to diagnose cutaneous leishmaniasis in horses in European countries such as Germany and Switzerland (Koehler et al., 2002; Müller et al.,
2009). Similar to our study, DNA fragments were amplified by ITS, ITS1, and ITS2 gene markers in the equine blood samples. Nevertheless, it was not possible to confirm the etiological agent of infection in those blood samples without RFLP. ITS gene amplification may indicate infection by other species of Leishmania or Trypanosoma or even a co-infection in these equine samples.

Moreover, RV1/RV2 primer pairs could also efficiently detect the genetic material of donovani complex in Brazilian dog samples and exhibited high sensitivity primarily due to high kDNA minicircle copy number of the target employed (Almeida et al., 2013; Bigeli, Oliveira Júnior, \& Teles, 2012; A. F. Silva et al., 2017). The PCR assay with primer pairs amplified kDNA sequences in 21 samples. Although the amplification was lower than that observed with other ITS and ITS2 primer pairs, in the BLAST platform they were able to amplify Leishmania genus sequences ( $L$. infantum, L. donovani, L. amazonensis, and L. major). The PCR primers targeting kDNA genes proved to be more suitable for detection of asymptomatic horses than those targeting ITS markers. We were able to confirm the presence of $L$. infantum in our samples through sequencing. In this way, we concluded that it was not feasible to perform screening with nonspecific primers for the diagnosis of Leishmania infection in equines, since not all positive animals were infected by the genus Leishmania. The specificity of these PCR primers was tested by their inability to amplify DNA from pathogens such as $T$. cruzi, E. canis, B. canis, and T. gondii (Almeida et al., 2013; Le Fichoux et al., 1999; R. C. Silva et al., 2017; Solcà et al., 2012).

Skin lesions as the main clinical manifestation was observed in $L$. infantum-infected horses (Koehler et al., 2002; Müller et al., 2015; Müller et al., 2009). However, anti-L. infantum antibodies were detected in healthy horses as well. Thus, we cannot consider lesions as a sign of infection, particularly in endemic areas (Fernández-Bellon et al., 2006). In this study, animals did not show 
clinical or cutaneous alterations, such as skin lesions or lymph node enlargement. Occult leishmaniasis documentation in asymptomatic animals is important for researchers in order to obtain more knowledge about the parasite reservoir and transmission as well as for better understanding of parasitic dissemination pathways and its capacity to survive in the host (Le Fichoux et al., 1999).

After vector identification and characterization of L. infantum-infected dog samples, the disease was observed to spread rapidly in Uruguaiana. All neighborhoods have CVL confirmed cases, and it has consequently been concluded that the vector has been maintained since then (Deboni et al., 2011; Escobar et al., 2018). Our study detected L. infantum DNA in equines from seven neighborhoods of Uruguaiana that were known to be the endemic foci of CVL, as notified by the Sanitary Surveillance of the Uruguaiana municipality. Two regions (Eastern and Western) had a higher number of infected horses. However, a limitation of the study included the inability to conduct an epidemiological survey of all neighborhoods as the traction horses were mostly domiciled in the peripheral regions of the city. These animals undergo intense movement during the day and are easily sold by their owners. This indicates a relation between these species and their contact with infected dogs, corroborating reports which suggest that equines can be infected when living in an endemic area and represent a source of feeding for the vectors present in endemic regions (MacedoSilva et al., 2014; Truppel et al., 2014). Therefore, the identification of new hosts and reservoirs that may participate in disease dissemination is imperative to understand the transmission cycle and to evaluate the need of control measures to prevent infection.

\section{Conclusions}

To our knowledge, this is the first report of equine infection with $L$. infantum in Southern Brazil. The kDNA PCR and sequencing allowed L. infantum detection in equine peripheral blood samples. These results proved that, as well as in European countries, L. infantum could also infect horses in addition to humans and dogs. They also emphasize the importance of following up the investigation in these animals as well as studying the chain of transmission, life cycle, and molecular characterization of the parasite.

\section{Acknowledgements}

We wish to thank Equipampa Group for their support in the sampling, the Federal University of Pampa (UNIPAMPA), the group of Biotechnology Center (CBiot) of Federal University of Rio Grande do Sul: Dr. Marilene Henning Vainstein, Dr. Lívia Kmetzsch Rosa e Silva, Dr. Augusto Schrank, and Dr. Ângela Junges for technical assistance in their laboratories. Karen Rocha is acknowledged for her help in revision of English language during the elaboration of the draft. We also thank the Oswaldo Cruz Institute (CLIOC-FIOCRUZ) for kindly providing Leishmania reference strains.

\section{Funding}

This study was supported by a grant from the FAPERGS ${ }^{10}$ (Research Support Foundation of Rio Grande do Sul) and Research Program for SUS: Shared Health Management PPSUS: DECIT/ SCTIE/MS, CNPq, FAPERG, and SES-RS ${ }^{11}$.

\footnotetext{
${ }^{10}$ See: http://fapergs.rs.gov.br/inicial (accessed 4 May 2017).

${ }^{11}$ See: http://fapergs.rs.gov.br/chamada-fapergs-ms-cnpq-sesrs-n-03-2017-ppsus (accessed 4 May 2017).
} 


\section{References}

Akhoundi, M., Downing, T., Votýpka, J., Kuhls, K., Lukeš, J., Cannet,... Kasbari, M. (2017). Leishmania infections: molecular targets and diagnosis. Molecular Aspects of Medicine, 57, 1-29. doi: 10.1016/j.mam.2016.11.012

Almeida, A. B., Sousa, V. R., Gasparetto, N. D., Silva, G. F. da, Figueiredo, F. B., Dutra, V., . . . Madeira, M. F. (2013). Canine visceral leishmaniasis: diagnostic approaches based on polymerase chain reaction employing different biological samples. Diagnostic Microbiology and Infectious Disease, 76(3), 321324. doi: 10.1016/j.diagmicrobio.2013.03.017

Belo, V. S., Werneck, G. L., Barbosa, D. S., Simões, T. C., Nascimento, B. W. L., Silva, E. S. da, \& Struchiner, C. J. (2013). Correction: factors associated with visceral leishmaniasis in the americas: a systematic review and meta-analysis. PLoS Neglected Tropical Diseases, 7(5). doi: 10.1371/annotation/838560448747-4d93-9a1e-64f16bb60c07

Benassi, J. C., Benvenga, G. U., Ferreira, H. L.; Pereira, V. F., Keid, L. B., Soares, R.,... Oliveira, T. M. F.S. (2017). Detection of Leishmania infantum DNA in conjunctival swabs of cats by quantitative real-time PCR. Experimental Parasitology, 177, 93-97. doi: 10.1016/j.exppara.2017.04.004

Bigeli, J. G., Oliveira Júnior, W. P. de, \& Teles, N. M. M. (2012). Diagnosis of Leishmania (Leishmania) chagasi infection in dogs and the relationship with environmental and sanitary aspects in the municipality of Palmas, state of Tocantins, Brazil. Revista da Sociedade Brasileira de Medicina Tropical, 45(1),18-23. doi: 10.1590/S003786822012000100005

Ministério da Saúde. (2014). Manual de vigilância e controle da leishmaniose visceral. Brasília: Ministério da Saúde - Divisão de Vigilância Epidemiológica.

Brito, C. F. P. C., \& Pita-Pereira, D. (2014). Diagnóstico molecular de Leishmania spp. em Flebótomos provenientes de áreas de ocorrência de leishmanioses. In F. da Conceição-Silva \& C. R. Alves. Leishmanioses do continente americano (Chap. 13, pp. 217-231). Rio de Janeiro: Editora FIOCRUZ.

Cortes, S.; Rolão, N.; Ramada, J., \& Campino, L. (2004). PCR as a rapid and sensitive tool in the diagnosis of human and canine leishmaniasis using Leishmania donovani sl-specific kinetoplastid primers. Transactions of the Royal Society of Tropical Medicine and Hygiene, 98(1), 12-17. doi: 10.1016/ S0035-9203(03)00002-6
Dantas-Torres, F. (2009). Canine leishmaniosis in South America. Parasites \& Vectors, 2(1), S1. doi: 10.1186/1756-3305-2-S1-S1

Deboni, S. C., Barbosa, M., \& Ramos, R. R. (2011). Leishmaniose Visceral no Rio Grande do Sul. Boletim Epidemiológico, 13 (1), 1-8. Retrived from: https://www.cevs.rs.gov.br/upload/arquivos/ 201812/27124724-n-1-marco.pdf

Echchakery, M., Chicharro, C., Boussaa, S., Nieto, J., Carrillo, E., Sheila, O.,... Boumezzough, A. (2017). Molecular detection of Leishmania infantum and Leishmania tropica in rodent species from endemic cutaneous leishmaniasis areas in Morocco. Parasites \& Vectors, 10(1), 454-462. doi: 10.1186/s13071017-2398-8

El Tai, N., Osman, O., El Fari, M., Presber, W., \& Schönian, G. (2000). Genetic heterogeneity of ribosomal internal transcribed spacer in clinical samples of Leishmania donovani spotted on filter paper as revealed by single-strand conformation polymorphisms and sequencing. Transactions of the Royal Society of Tropical Medicine and Hygiene, 94(5), 575-579. doi: 10.1016/S0035-9203(00)900932

El Tai, N. O., El Fari, M., Mauricio, I., Miles, M. A., Oskam, L., El Safi, S. H.,... Schönian, G. (2001). Leishmania donovani: intraspecific polymorphisms of Sudanese isolates revealed by PCR-based analyses and DNA sequencing. Experimental Parasitology, 97(1), 35-44. doi: 10.1006/expr.2001.4592

Escobar, T. A., Döwich, G., Zuravski, L., Cantele, L. C., Duarte, C. A., \& Lübeck, I. (2018). Risk factors associated to canine visceral leishmaniasis in Uruguaiana city, Brazil. Semina: Ciências Agrárias, 39(1), 211-219. Retrived from http://dx.doi. org/10.5433/1679-0359.2018v39n1p211

Feitosa, F. L. F., Leal, J., Mendes, L. C. N., Peiro, J. R., Perri, S. H. V., Lima, V. M. F. de,... Marcondes, M. (2012). Estudo soroepidemiológico de leishmaniose em equinos na região de Araçatuba-SP, Brasil, área endêmica para leishmaniose visceral. Brazilian Journal of Veterinary Research and Animal Science, $49(6)$, 500-502. Retrived from http://dx.doi. org/10.11606/issn.1678-4456.v49i6p500-502

Fernández-Bellon, H., Solano-Gallego, L., Bardagí, M., Alberola, J., Ramis, A., \& Ferrer, L. (2006). Immune response to Leishmania infantum in healthy horses in Spain. Veterinary Parasitology, 135(2),181185. Retrived from https://dx.doi.org/1016/j. vetpar.2005.09.007 
Figueiredo, F., \& Madeira, M. de F. (2014). Os parasitos e a questão da infecção em animais domésticos e domiciliados. In F. da Conceição-Silva \& C. R. Alves. Leishmanioses do continente americano (Chap. 15, pp. 259-273). Rio de Janeiro: Editora FIOCRUZ.

Gama, A., Elias, J., Ribeiro, A. J., Alegria, N., Schallig, H. D., Silva, F.,... Cotovio, M. (2014). Cutaneous leishmaniosis in a horse from northern Portugal. Veterinary Parasitology, 200(1), 189-192. Retrived from https://dx.doi.org/10.1016/j.vetpar.2013.12.005

Koehler, K., Stechele, M., Hetzel, U., Domingo, M., Schönian, G., Zahner, H., \& Burkhardt, E. (2002). Cutaneous leishmaniosis in a horse in southern Germany caused by Leishmania infantum. Veterinary Parasitology, 109(1), 9-17. doi: 10.1016/S03044017(02)00246-7

Kuhls, K., Mauricio, I. L., Pratlong, F., Presber, W., \& Schönian, G. (2005). Analysis of ribosomal DNA internal transcribed spacer sequences of the Leishmania donovani complex. Microbes and Infection, 7(11-12), 1224-1234. doi: doi. org/10.1016/j.micinf.2005.04.009

Lainson, R., \& Rangel, E. F. (2005). Lutzomyia longipalpis and the eco-epidemiology of American visceral leishmaniasis, with particular reference to Brazil: a review. Memórias do Instituto Oswaldo Cruz, 100(8), 811-827. doi: 10.1590/S007402762005000800001

le Fichoux, Y., Quaranta, J.-F., Aufeuvre, J.-P., Lelievre, A., Marty, P., Suffia, I.,... Kubar, J. (1999). Occurrence of Leishmania infantum parasitemia in asymptomatic blood donors living in an area of endemicity in southern France. Journal of Clinical Microbiology, 37(6), 1953-1957.

Lombardi, M. C., Turchetti, A. P., Tinoco, H. P., Pessanha, A. T., Soave, S. A., Malta, M. C.,... Santos, R. L. (2014). Diagnosis of Leishmania infantum infection by polymerase chain reaction in wild mammals. Pesquisa Veterinária Brasileira, 34(12), 1243-1246. doi: 10.1590/S0100-736X2014001200017

Lombardo, G., Pennisi, M. G., Lupo, T., Chicharro, C., \& Solano-Gallego, L. (2014). Papular dermatitis due to Leishmania infantum infection in seventeen dogs: diagnostic features, extent of the infection and treatment outcome. Parasites \& Vectors 7(1), 120131. doi: 10.1186/1756-3305-7-120

Lopes, E., Sevá, A., Ferreira, F., Nunes, C., Keid, L., Hiramoto, R., . . . Galvis-Ovallos, F. (2017). Serological and molecular diagnostic tests for canine visceral leishmaniasis in Brazilian endemic area: one out of five seronegative dogs are infected. Epidemiology \& Infection, 145(12), 2436-2444. Retrived from https://doi-org.ez96.periodicos.capes. gov.br/10.1017/S0950268817001443

Lukeš, J., Guilbride, D. L., Votýpka, J., Zíková, A., Benne, R., \& Englund, P. T. (2002). Kinetoplast DNA network: evolution of an improbable structure. Eukaryotic cell, 1(4), 495-502. doi: 10.1128/ EC.1.4.495-502.2002

Macedo-Silva, V. P., Martins, D. R., Queiroz, P. V. S. de., Pinheiro, M. P. G., Freire, C. C., Queiroz, J. W., . . . Jeronimo, S. M. (2014). Feeding preferences of Lutzomyia longipalpis (Diptera: Psychodidae), the sand fly vector, for Leishmania infantum (Kinetoplastida: Trypanosomatidae). Journal of Medical Entomology 51(1), 237-244. doi: 10.1603/ ME12131

Müller, N., Hentrich, B., Frey, C. F., \& Welle, M. (2015). Quantitative PCR for the diagnosis of cutaneous leishmaniasis from formalin-fixed and paraffin-embedded skin sections. Molecular and Cellular Probes, 29(6), 507-510. doi: 10.1016/j. mcp.2015.09.008

Müller, N., Welle, M., Lobsiger, L., Stoffel, M. H., Boghenbor, K. K., Hilbe, M.,... Von Bomhard, W. (2009). Occurrence of Leishmania sp. in cutaneous lesions of horses in Central Europe. Veterinary Parasitology, 166(3), 346-351. doi: 10.1016/j. vetpar.2009.09.001

Pandey, K., Pant, S., Kanbara, H., Shuaibu, M. N., Mallik, A. K., Pandey, B. D.,... Yanagi, T. (2008). Molecular detection of Leishmania parasites from whole bodies of sandflies collected in Nepal. Parasitology Research, 103(2), 293-297. doi: 10.1007/s00436008-0967-7

Pita-Pereira, D., Lins, R., Oliveira, M. P., Lima, R. B., Pereira, B. A., Moreira, O. C.,... Britto, C. (2012). SYBR Green-based real-time PCR targeting kinetoplast DNA can be used to discriminate between the main etiologic agents of Brazilian cutaneous and visceral leishmaniasis. Parasites \& Vectors, 5(1), 5-15. doi: 10.1186/1756-3305-5-15

Sambrook, J., \& Russel, D. W. (2001). Molecular cloning: a laboratory manual (Rev. ed.). (Chap. 1, pp. 21-27). New York: Cold Spring Harbor: Cold spring harbor laboratory press.

Schönian, G., Nasereddin, A., Dinse, N., Schweynoch, C., Schallig, H. D., Presber, W., \& Jaffe, C. L. (2003). PCR diagnosis and characterization of Leishmania 
in local and imported clinical samples. Diagnostic Microbiology and Infectious Disease, 47(1), 349358.

Schönian, G., Schnur, L., El Fari, M., Oskam, L., Kolesnikov, A. A., Sokolowska-Köhler, W., \& Presber, W. (2001). Genetic heterogeneity in the species Leishmania tropica revealed by different PCR-based methods. Transactions of the Royal Society of Tropical Medicine and Hygiene, 95(2), 217-224. doi: 10.1016/S0035-9203(01)90173-7

Silva, A. F. da, Damasceno, Á. R. A., Prado, W. S., Caldeira, R. D., Sampaio-Junior, F. D., Farias, D. M. de, .. . G., Scofield, A. (2017). Leishmania infantum infection in dogs from maroon communities in the Eastern Amazon. Ciência Rural, 47, e20160025. doi: $10.1590 / 0103-8478$ cr20160025

Silva, M. A. L. da, Medeiros, R. A., Brandão-Filho, S., Melo, F. L., \& Medeiros, Z. (2010). Alvos moleculares utilizados em PCR para o diagnóstico da leishmaniose visceral humana. Revista Eletrônica de Farmácia, 7(3), 1-15. doi: 10.5216/ref.v7i3.12947

Silva, R. C., Richini-Pereira, V. B., Kikuti, M., Marson, P. M., \& Langoni, H. (2017). Detection of Leishmania (L.) infantum in stray dogs by molecular techniques with sensitive species-specific primers. Veterinary Quarterly, 37(1), 23-30. doi: $10.1080 / 01652176.2016 .1252073$

Soares, I. R., Silva, S. O., Moreira, F. M., Prado, L. G., Fantini, P., Maranhão, R. de P. A.,... Palhares, M. S. (2013). First evidence of autochthonous cases of
Leishmania (Leishmania) infantum in horse (Equus caballus) in the Americas and mixed infection of Leishmania infantum and Leishmania (Viannia) braziliensis. Veterinary Parasitology, 197(3), 665669. doi: 10.1016/j.vetpar.2013.06.014

Solano-Gallego, L., Fernàndez-Bellon, H., Serra, P., Gállego, M., Ramis, A., Fondevila, D., \& Ferrer, L. (2003). Cutaneous leishmaniosis in three horses in Spain. Equine Veterinary Journal, 35(3), 320-323. R doi: 10.2746/042516403776148336:

Solcà, M. da S., Guedes, C. E. S., Nascimento, E. G., Oliveira, G. G. de S., Santos, W. L. C. dos, Fraga, D. B. M., \& Veras, P. S. T. (2012). Qualitative and quantitative polymerase chain reaction (PCR) for detection of Leishmania in spleen samples from naturally infected dogs. Veterinary Parasitology, 184(2-4), 133-140. doi: 10.1016/j.vetpar.2011.08.026

Souza, N. P., Almeida, A. do B. P. F. de, Freitas, T. P. T. de, Paz, R. C. R. da, Dutra, V., Nakazato, L., \& Sousa, V. R. F. (2010). Leishmania (Leishmania) infantum chagasi em canídeos silvestres mantidos em cativeiro, no Estado de Mato Grosso. Revista da Sociedade Brasileira de Medicina Tropical, 43(3), 333-335. doi: 10.1590/S0037-86822010000300024

Truppel, J. H., Otomura, F., Teodoro, U., Massafera, R., Costa-Ribeiro, M. C. V. da, Catarino, C. M.,... Thomaz-Soccol, V. (2014). Can equids be a reservoir of Leishmania braziliensis in endemic areas? PLoS ONE, 9(4), e93731. doi: 10.1371/journal. pone.0093731 
